\title{
Ventilatory frequency and anesthetic efficacy in silver catfish, Rhamdia quelen: a comparative approach between different essential oils
}

\section{Alessandra Janaína Becker ${ }^{1}$ (D), Carine de Oliveira Fogliarini ${ }^{1}$ (D), Carine de Freitas Souza ${ }^{1}$ (D), Alexssandro Geferson Becker ${ }^{2}$ (iD), Rosa Helena Veras Mourão ${ }^{3}$ (iD), Lenise Vargas Flôres da Silva $^{4}$ iD, Bernardo Baldisserotto ${ }^{1 *}$}

\footnotetext{
${ }^{1}$ Universidade Federal de Santa Maria, Departamento de Fisiologia e Farmacologia, Santa Maria, RS, Brasil.

${ }^{2}$ Universidade Federal do Paraná, Departamento de Zootecnia, Setor Palotina, Palotina, PR, Brasil.

${ }^{3}$ Universidade Federal do Oeste do Pará, Laboratório de Bioprospecção e Biologia Experimental, Santarém, PA, Brasil.

${ }^{4}$ Universidade Federal do Oeste do Pará, Instituto de Ciências e Tecnologia das Águas, Santarém, PA, Brasil.
}

\begin{abstract}
This study investigated the efficacy of essential oils of Lippia alba (EOLA) citral chemotype and Lippia origanoides (EOLO) and their effects on ventilatory frequency (VF) of silver catfish, Rhamdia quelen. Fish were exposed to $50-300 \mu \mathrm{L} \mathrm{L}^{-1}$ of EOLA and $25-300 \mu \mathrm{L} \mathrm{L}^{-1}$ of EOLO to determine induction times to sedation, anesthesia, and recovery. Moreover, VF was determined in fish exposed to 5 or $10 \mu \mathrm{L} \mathrm{L}^{-1}$ of EOLA and of EOLO for $8 \mathrm{~h}$. The increasing concentration of essential oils proportionally decreased sedation and anesthesia induction times. The highest EOLA concentration increased $\mathrm{VF}$ of fish from the control group at $1 \mathrm{~h}$ of exposure, but VF decreased at both EOLO concentrations after $2 \mathrm{~h}$. The EOLA citral chemotype and EOLO were effective sedatives and anesthetics for silver catfish. However, EOLO was the most suitable sedative for additional studies regarding fish transport as it reduced VF and did not induce VF increase in silver catfish. The EOLA citral chemotype and EOLO are effective sedatives and anesthetics for silver catfish. Moreover, the EOLO is recommended for transport of silver catfish, because it maintains the ventilatory frequency constant, avoiding a possible metabolic stress.
\end{abstract}

Key Words: aquaculture, fish, physiology, Rhamdia quelen

\section{Introduction}

Fish maintained in culture systems and experimental laboratories are susceptible to stressful situations caused by capture, handling, or confinement, possibly causing behavioral, physiological, biochemical, and molecular changes, which can compromise production or experimentation (Barton and Iwama, 1991; Mommsen et al., 1999; Barton, 2002). In view of this, the use of anesthetics obtained from plants (extracts or essential oils) has been investigated, with the result that several of these substances are effective in reducing and/or minimizing stress responses (Cunha et al., 2010a; 2010b; 2011; Becker et al., 2012; 2013; Silva et al., 2012; 2013; Gressler et al., 2014; Parodi et al., 2014; Toni et al., 2014; 2015; Zeppenfeld et al., 2014; Salbego et al., 2014; 2015).

Received: July 4, 2017

Accepted: May 11, 2018

*Corresponding author: bbaldisserotto@hotmail.com

Copyright (C) 2018 Sociedade Brasileira de Zootecnia. This is an Open Access article distributed under the terms of the Creative Commons Attribution License (http://creativecommons.org/licenses/by/4.0/), which permits unrestricted use, distribution, and reproduction in any medium, provided the original work is properly cited.
The genus Lippia (Verbenaceae) includes approximately 250 species of shrubs, small trees, and herbs and is widely distributed in southern and central American countries, Tropical Africa, the southern United States of America, India, and Australia (Bezerra et al., 1981; Terblanché and Kornelius, 1996; Singh et al., 2000; Day and McAndrew, 2003; Hennebelle et al., 2008). The essential oil (EO) of Lippia alba (Mill.) N.E. Brown linalool chemotype (EOLA) is a suitable anesthetic for several fish species (Cunha et al., 2010a, 2011; Toni et al., 2014, 2015; Hohlenwerger et al., 2016); the citral chemotype presented similar anesthetic effect for silver catfish, Rhamdia quelen (Quoy and Gaimard, 1824). The EO of Aloysia tryphilla, which contains citral as the main compound, also has anesthetic efficacy in silver catfish (Gressler et al., 2014; Parodi et al., 2014). However, no studies regarding fish anesthesia have been performed with Lippia origanoides Humboldt, Bonpland, and Kunth, popularly known in northern Brazil as "salva-de-marajó", a shrub occurring in southern North America to northern South America (Stashenko et al., 2010). The EO of Lippia sidoides, a synonymy of $L$. origanoides (O'Leary et al., 2012), revealed anesthetic activity in silver catfish, but caused mucus loss and mortality (Silva et al., 2013). 
Therefore, the present study is the first to report the efficacy of EO of $L$. origanoides (EOLO) and EOLA as anesthetics in fish. Moreover, we analyzed ventilatory frequency to help understand the effects of these EO on fish behavior.

\section{Material and Methods}

Silver catfish $(40.88 \pm 1.21 \mathrm{~g}, 17.02 \pm 0.16 \mathrm{~cm})$ juveniles were obtained from a local fish culture and transferred to a laboratory. Fish were maintained in continuously aerated tanks $(250 \mathrm{~L})$ with controlled water parameters (mean $\pm \mathrm{SEM})$ : dissolved oxygen $\left(6.73 \pm 0.07 \mathrm{mg} \mathrm{L}^{-1}\right)$, temperature $\left(20.07 \pm 0.02{ }^{\circ} \mathrm{C}\right), \mathrm{pH}(6.72 \pm 0.14)$, alkalinity $\left(47.40 \pm 0.80 \mathrm{mg} \mathrm{CaCO}_{3} \mathrm{~L}^{-1}\right)$, total ammonia nitrogen

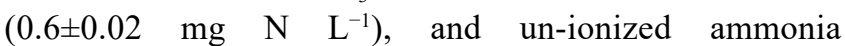
$\left(0.0042 \pm 0.0003 \mathrm{mg} \mathrm{N} \mathrm{L}^{-1}\right)$. The photoperiod was $12 \mathrm{~h}$ light $/ 12 \mathrm{~h}$ dark. We used a semi-static system and changed $50 \%$ of the water volume daily to remove uneaten food, residues, and feces. The juveniles were fed twice a day (5.0\% biomass) with commercial feed ( $28 \%$ crude protein).

Dissolved oxygen and temperature were determined with a YSI oxygen meter (Model Y5512; YSI Inc., Yellow Springs, OH, USA); pH, with a DMPH-2 pH meter (Digimed, SP, Brazil); alkalinity, according to Boyd and Tucker (1992); total ammonia nitrogen levels, through the salicylate method (Verdouw et al., 1978); and un-ionized ammonia was obtained from a conversion table for fresh water.

The methodology of this experiment was approved by the local Ethical and Animal Welfare Committee (case no. 046/2010).

Leaves of L. alba were collected in Santarém (Pará, Brazil) in June 2012, and identification was performed by Dr. Fátima Salimena (voucher number CESJ 65276, Universidade Federal de Juiz de Fora, Minas Gerais, Brazil). Leaves of $L$. origanoides were collected in August 2008 in Alter do Chão (Santarém, Pará, Brazil), also identified by Dr. Salimena, and the voucher was deposited in Empresa Brasileira de Pesquisa Agropecuária (EMBRAPA) under the number IAN 184688.

Extraction of EO was performed by hydrodistillation for 3 or $6 \mathrm{~h}$ through a Clevenger-type apparatus (European Pharmacopoeia, 2007). About $100 \mathrm{~g}$ of fresh leaves were immersed in distilled water at a ratio of 1:10 (w/v), and the oil was separated from water after reaching room temperature. Average yield was 1.4\% EOLA and 2.7\% EOLO. Essential oils were transferred to glass flasks, filled to the top, and kept at a temperature of $10^{\circ} \mathrm{C}$ for further analysis.

Analysis of EOLA and EOLO by gas chromatographymass spectrometry-thin ion chromatography was performed using an Agilent-6890 gas chromatograph coupled with an Agilent 5973 mass selective detector with a HP5-MS column (5\% phenyl, 95\% methylsiloxane, $30 \mathrm{~m} \times 0.25 \mathrm{~mm}$ i.d. $\times 0.25 \mu \mathrm{m})$ as described by Silva et al. (2012). The chemical constituents of these EO were identified by comparison of the Kovats retention index and mass spectra with a mass spectral library and literature data (NIST/EPA/NIH, 2005; Adams, 2007; Mondello, 2011).

Fish were transferred to $1-\mathrm{L}$ aquaria $(\mathrm{n}=10$ each concentration) and exposed to the following $\mathrm{EO}$ concentrations (in $\mu \mathrm{L} \mathrm{L}^{-1}$ ): 50, 100, 150, 200, and 300 of EOLA and 25, 50, 100, 200, and 300 of EOLO. All EO were previously diluted in ethanol (1:10). The concentrations tested were slightly different between the EO because their efficacy was variable (see results). Induction times of sedation and anesthesia as well as recovery were evaluated, and anesthesia stages were characterized as described by Small (2003), with a maximum observation time of $30 \mathrm{~min}$. Silver catfish were placed in an aquarium with anestheticfree water for recovery. We used a digital chronometer to record all times, expressed in seconds.

The second experiment determined ventilatory frequency (VF) using concentrations with potential application in transporting procedures. Ventilatory frequency was quantified at $0,0.25,1,2,4$, and $8 \mathrm{~h}$ of exposure, as reported by Alvarenga and Volpato (1995): visual count of 20 successive buccal or opercular movements, recording the elapsed time with a digital chronometer. We used the following EO concentrations (previously diluted in ethanol and expressed in $\mu \mathrm{L} \mathrm{L}^{-1}$ ): 5 or 10 for EOLA and 5 or 10 for EOLO. Moreover, water (control) and ethanol groups were evaluated.

All results were expressed as mean \pm SEM. Evaluation of anesthetic activity was performed by regression analysis (concentration $\times$ time of anesthesia induction; concentration $\times$ time of recovery from anesthesia), using the SigmaPlot version 11.0 software. The homogeneity of variances of VF data was tested with Levene's test. These data did not show homoscedasticity and were subjected to Kruskal-Wallis ANOVA, followed by multiple comparisons of mean ranks for all groups. The software used was Statistica 7.0 (Stat Soft, Tulsa, OK), and the minimum significance level was set at $\mathrm{P}<0.05$.

\section{Results}

The major components of EOLA were geranial $(30.02 \%)$, neral $(25.26 \%)$, and limonene $(9.11 \%)$, while EOLO was mainly comprised of carvacrol $(47.20 \%)$, thymol $(12.80 \%)$, and p-cymene $(9.70 \%)$ (Table 1$)$. 
Table 1 - Chemical composition of the essential oils of Lippia alba (EOLA) and Lippia origanoides (EOLO)

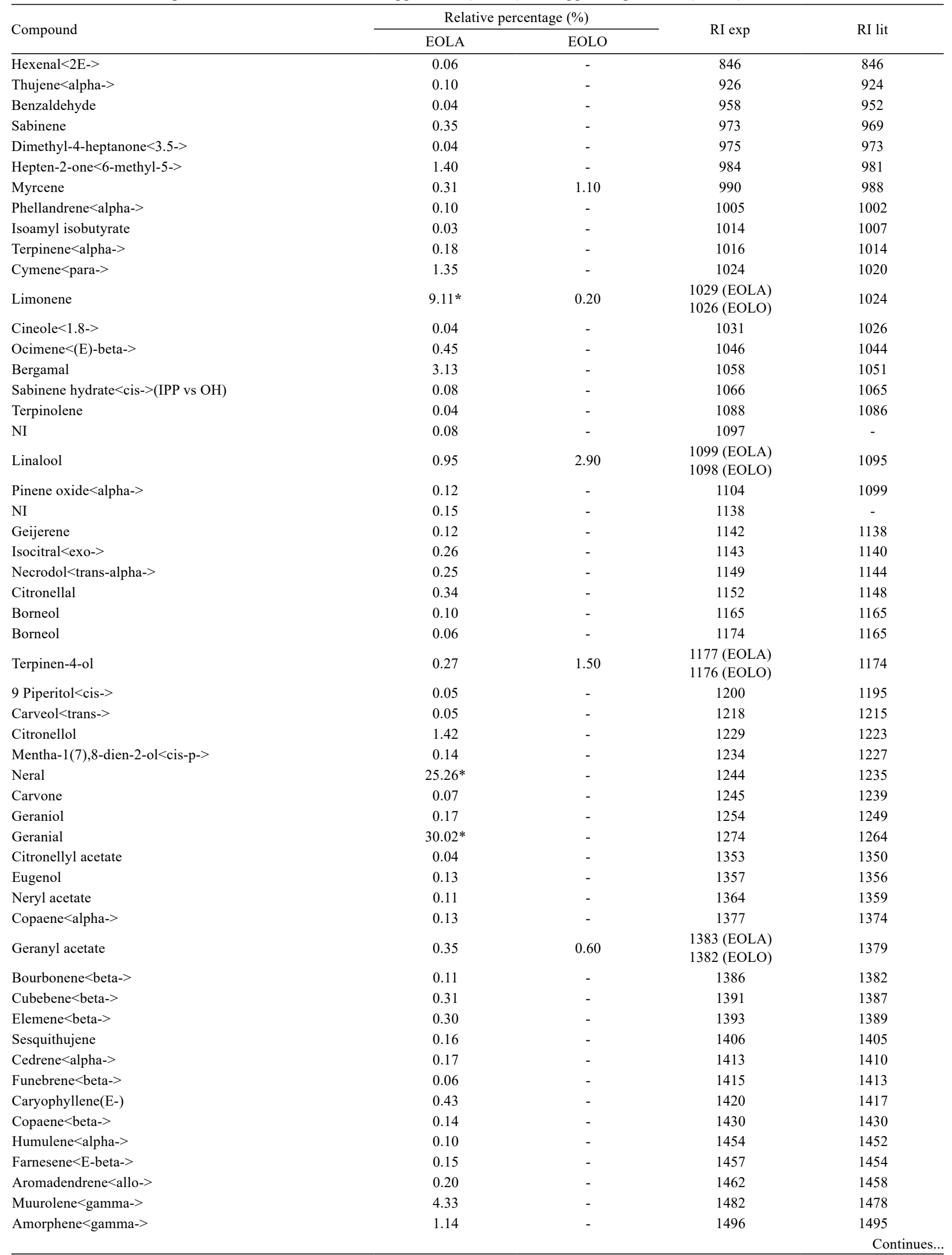


Table 1 (Continued)

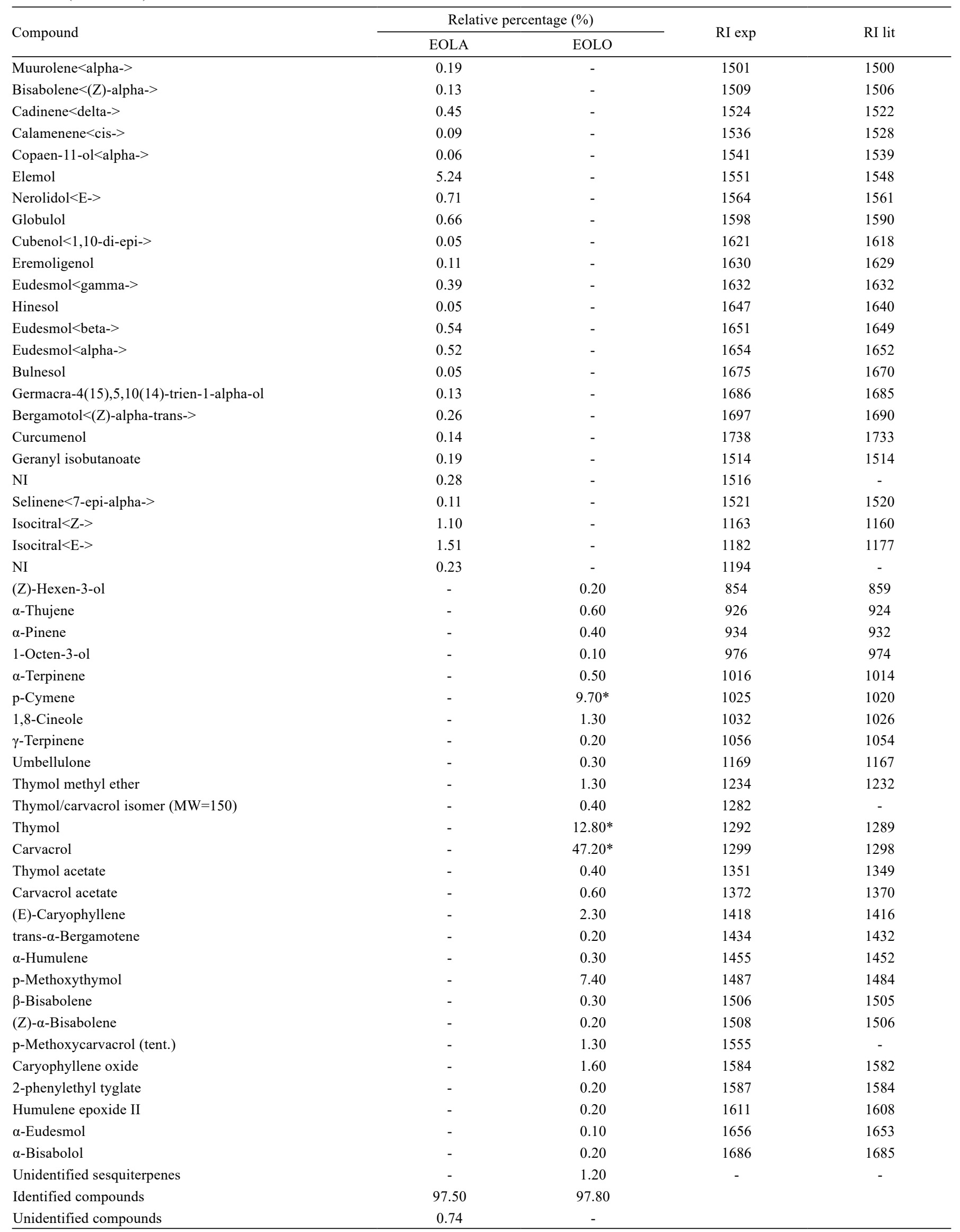

NI - not identified component; RI experimental - calculated Kovats retention index; RI literature - reference Kovats retention index (Adams (31), NIST (32), Mondello (33)).

${ }^{*}$ Relative percentage of main compounds. 
Time to induce sedation with EOLA decreased to around $150 \mu \mathrm{L} \mathrm{L}^{-1}$, i.e., higher concentrations did not reduce time to induce sedation, and increasing concentration of EOLA proportionally decreased anesthesia induction time (Figure 1A). The lowest concentration of EOLO $\left(25 \mu \mathrm{L} \mathrm{L}^{-1}\right)$ was only sedative to silver catfish, and equation revealed that concentrations higher than $300 \mu \mathrm{L} \mathrm{L}^{-1}$ do not decrease time to induce sedation with EOLO. Increasing concentrations of EOLO proportionally decreased anesthesia induction times, but concentrations higher than $150 \mu \mathrm{L} \mathrm{L}^{-1}$ did not decrease time to induce anesthesia with EOLO (Figure 1B). Recovery time increased proportionally up to around 150 and $100 \mu \mathrm{L} \mathrm{L}^{-1}$ EOLA and EOLO, respectively (Figure 1).

Ventilatory frequency of the control group decreased significantly $15 \mathrm{~min}$ after fish were placed in the aquaria and kept unchanged for $8 \mathrm{~h}$. Silver catfish exposed to ethanol also progressively reduced VF up to $4 \mathrm{~h}$, with significantly higher values than those for control fish after exposure of $15 \mathrm{~min}$ to $1 \mathrm{~h}$. Fish exposed to EOLA presented lower VF than control and/or ethanol groups in some measurements, but the highest EOLA concentration also increased $\mathrm{VF}$ at $1 \mathrm{~h}$. Ventilatory frequency values of fish exposed to both concentrations of EOLO from $15 \mathrm{~min}$ to $8 \mathrm{~h}$ were significantly lower than those in control and ethanol groups in all measurements, with the exception of $1 \mathrm{~h}$ for the highest concentration of EOLO, in which the values were similar to those in the control (Table 2).

\section{Discussion}

Essential oil of Lippia alba citral chemotype used in the present study had citral $(55.28 \%$ geranial + neral) as major constituent, therefore belonging to the citral chemotype (Hennebelle et al., 2008), which was previously observed in another city of Minas Gerais, albeit with a lower citral content (Oliveira et al., 2006). The lowest EOLA concentration used in the present experiment $\left(50 \mu \mathrm{L} \mathrm{L}^{-1}\right)$ sedated silver catfish within 8 min, and a concentration of $200 \mu \mathrm{L} \mathrm{L}^{-1}$ was needed to anesthetize this species within $3 \mathrm{~min}$, in agreement with the results observed by Souza et al. (2017) in the same species. A. triphylla EO, which has citral as its main compound (72\% E-citral + Z-citral) (Parodi et al., 2012) also sedated silver catfish within $8 \mathrm{~min}$ at $50 \mu \mathrm{L} \mathrm{L}^{-1}$ (Parodi et al. 2014), but a concentration of $200 \mu \mathrm{L} \mathrm{L}^{-1}$ induced anesthesia after 6 to $10 \mathrm{~min}$, depending on fish size (Gressler et al., 2014, Parodi et al., 2014). Even considering fish size, EOLA citral chemotype was more efficient in anesthetizing silver catfish than A. triphylla EO, which can probably be explained by the presence of limonene (around 9\%) in EOLA. Limonene is the main compound (97.66\%) of the Citrus sinensis EO, which has an anxiolytic effect in Wistar rats (Faturi et al., 2010).

The main compound of EOLO was carvacrol (47.20\%), which corresponds to the carvacrol chemotype of $L$. origanoides (Stashenko et al., 2010). The anesthetic effect of EOLO in silver catfish was expected because,
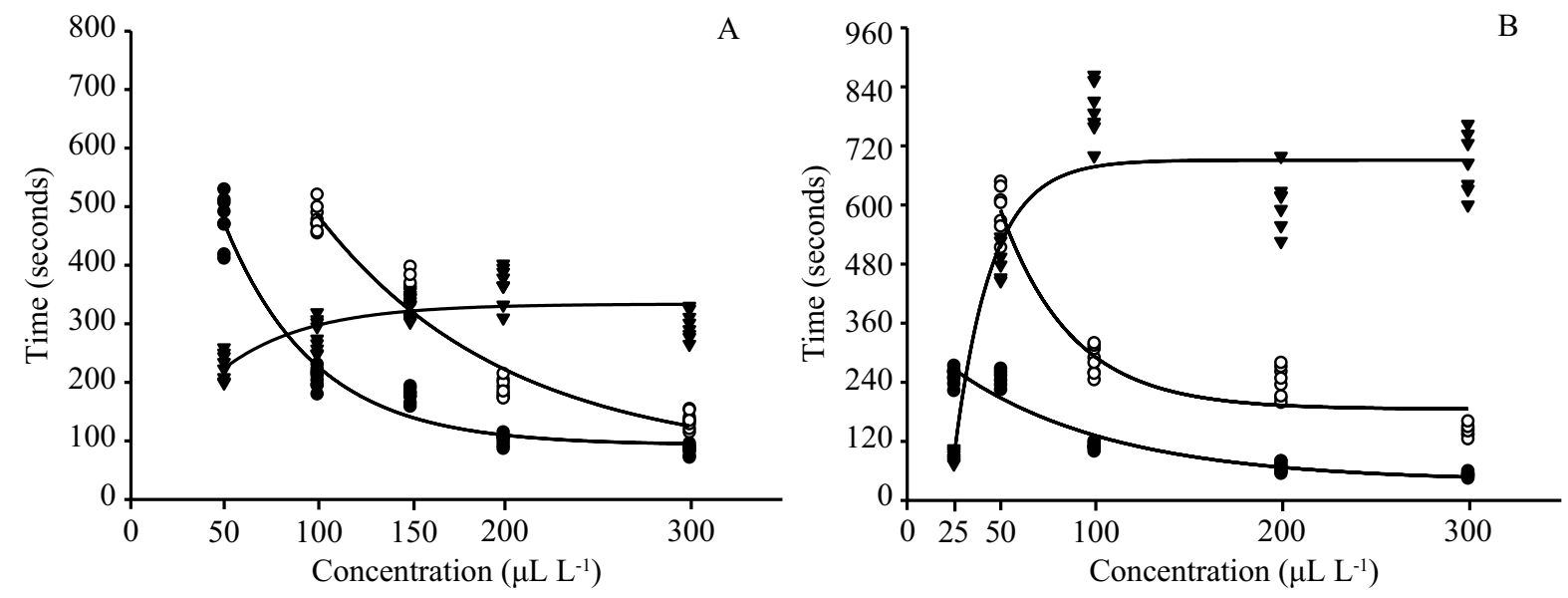

- Sedation $\circ$ Anesthesia $\nabla$ Recovery

The following equations were fitted to the data: L. alba (sedation: $\mathrm{y}=92.938+1066.002 \mathrm{e}^{(-0.021 \mathrm{x})}, \mathrm{r}^{2}=0.959 ;$ anesthesia: $\mathrm{y}=67.446+1127.087 \mathrm{e}^{(-0.010 \mathrm{x})}, \mathrm{r}^{2}=0.952 ;$ recovery: $\left.\mathrm{y}=1.727+331.991 *\left(1-\mathrm{e}^{(-0.022 \mathrm{x})}\right), \mathrm{r}^{2}=0.577\right)$, and L. origanoides $\left(\right.$ sedation: $\mathrm{y}=38.636+306.390 \mathrm{e}^{(-0.012 x)}, \mathrm{r}^{2}=0.932 ;$ anesthesia: $\mathrm{y}=185.427+1512.793 \mathrm{e}^{(-0.026 \mathrm{x})}, \mathrm{r}^{2}=0.929 ;$ recovery: $\left.\mathrm{y}=-1457.050+2148.272 *\left(1-\mathrm{e}^{(-0.051 \mathrm{x})}\right), \mathrm{r}^{2}=0.906\right)$.

Figure 1 - Times required for induction and recovery from anesthesia in silver catfish, Rhamdia quelen, exposed to the essential oils of Lippia alba (A) and Lippia origanoides (B). 
Table 2 - Effects of the essential oils of Lippia alba (EOLA) and Lippia origanoides (EOLO) on ventilatory frequency (opercular or buccal movements $\mathrm{min}^{-1}$ ) of silver catfish (Rhamdia quelen)

\begin{tabular}{|c|c|c|c|c|c|c|}
\hline \multirow{2}{*}{$\begin{array}{l}\text { Time of } \\
\text { exposure (h) }\end{array}$} & \multicolumn{6}{|c|}{ Group } \\
\hline & \multicolumn{2}{|c|}{ Control } & \multicolumn{2}{|c|}{ EOLA } & \multicolumn{2}{|c|}{ EOLO } \\
\hline 0 & $72.30 \pm 2.43 \mathrm{ABa}$ & $79.21 \pm 2.56 \mathrm{Aa}$ & $78.60 \pm 1.39 \mathrm{Aa}$ & $69.60 \pm 2.08 \mathrm{Bb}$ & $75.16 \pm 1.98 \mathrm{ABa}$ & $43.70 \pm 2.03 \mathrm{Cab}$ \\
\hline 1 & $48.57 \pm 1.92 \mathrm{Cb}$ & $62.44 \pm 1.98 \mathrm{Bc}$ & $46.35 \pm 1.93 \mathrm{Cb}$ & $85.91 \pm 1.93 \mathrm{Aa}$ & $36.31 \pm 1.71 \mathrm{Db}$ & $52.04 \pm 2.28 \mathrm{Ba}$ \\
\hline 2 & $55.32 \pm 1.96 \mathrm{ABb}$ & $51.76 \pm 1.67 \mathrm{ABd}$ & $44.14 \pm 2.27 \mathrm{BCb}$ & $66.50 \pm 2.21 \mathrm{Ab}$ & $30.84 \pm 0.92 \mathrm{Cb}$ & $32.08 \pm 1.89 \mathrm{Cbc}$ \\
\hline 4 & $49.52 \pm 1.32 \mathrm{Ab}$ & $42.09 \pm 2.02 \mathrm{Ae}$ & $45.69 \pm 2.26 \mathrm{Ab}$ & $43.45 \pm 2.32 \mathrm{Ac}$ & $30.17 \pm 1.44 \mathrm{Bb}$ & $25.41 \pm 1.09 \mathrm{Bc}$ \\
\hline
\end{tabular}

SEM - standard error of the mean.

Values are means \pm SEM.

Different uppercase letters in the rows indicate significant differences between groups in the same time $(\mathrm{P}<0.05)$

Different lowercase letters in the columns indicate significant differences between times in the same group $(\mathrm{P}<0.05)$.

in a study by Silva et al. (2013), L. sidoides EO (67.89\% carvacrol) induced anesthesia in this species. Time to induce sedation with the lowest EOLO concentration in this experiment was similar, but time to induce anesthesia (around 1 min with 200-300 $\mu \mathrm{L} \mathrm{L}^{-1}$ ) was much shorter than in the study of Silva et al. (2013) (around 20 min with 150$300 \mu \mathrm{L} \mathrm{L}^{-1}$ ). In addition, the results of our study differed in several other aspects from those of Silva et al. (2013): we observed no involuntary contractions and jumping behavior toward the surface, and all fish recovered within 10-11 min, even at the highest concentration tested. As carvacrol inhibits acetylcholinesterase activity in vitro (Jukic et al., 2007), Silva et al. (2013) hypothesized that this compound could be mainly responsible for involuntary contractions and jumping behavior of silver catfish exposed to L. sidoides EO. However, carvacrol had an anxiolytic-like effect in one study (Melo et al., 2010) and increased the latency for the development of convulsions in mice (Quintans-Júnior et al., 2010). It also blocks neuronal excitability by a direct inhibition of the voltagegated sodium current (Joca et al., 2012), which is similar to the mechanism of action of eugenol (Cho et al., 2008), an effective anesthetic in silver catfish (Cunha et al., 2010b).

Ventilatory frequency of control fish decreased a few minutes after they were placed in aquaria. This was expected, because the presence of the anesthetic in the water may provoke a transitory stress which increases VF levels, as observed previously in this species (Becker et al., 2012). The same was observed in silver catfish exposed to $10-20 \mu \mathrm{L} \mathrm{L} \mathrm{L}^{-1}$ EOLA chemotype linalool (Becker et al., 2012). The use of anesthetic concentrations (150$450 \mu \mathrm{L} \mathrm{L}^{-1}$ ) of EOLA chemotype linalool also induced the same VF response (Toni et al., 2014). The EOLA chemotype citral, used in the present experiment, reduced VF in some measurements. In addition, anesthesia with this EO also prevented the increase of plasma cortisol in silver catfish caused by handling (Souza et al., 2017;
2018). However, anesthesia with EOLA citral chemotype increased protein carbonylation levels in the kidney and liver of silver catfish, indicating that this EO may provoke renal and hepatic damage (Souza et al., 2018). There are no studies regarding VF of fish exposed to this EO or to A. triphylla EO. It is therefore not clear if $A$. triphylla EO reduced metabolism, because, at the end of $5 \mathrm{~h}$ of transport of silver catfish, $\mathrm{CO}_{2}$ levels of the water were lower, but $\mathrm{O}_{2}$ levels remained unchanged (Parodi et al., 2014). Essentia oil of $L$. origanoides was the most effective EO to reduce VF and apparently did not induce any initial stress response.

\section{Conclusions}

The essential oils of Lippia alba citral chemotype and Lippia origanoides are effective sedatives and anesthetics for silver catfish. Moreover, the essential oils of Lippia origanoides are recommended for transport of silver catfish, because they maintain the ventilatory frequency constant, reducing a possible metabolic stress.

\section{Acknowledgments}

The authors thank Dr. Fátima Salimena, for the identification of $L$. alba and L. origanoides. They also thank the Conselho Nacional de Desenvolvimento Científico e Tecnológico (CNPq; process 470964/2009-0), Coordenação de Aperfeiçoamento de Pessoal de Nível Superior (CAPES), Fundação de Amparo à Pesquisa do Estado do Rio Grande do Sul (FAPERGS; 10/0016-8), and INCT-ADAPTA 2.

\section{References}

Adams, R. P. 2007. Identification of essential oil components by gas chromatography/mass spectrometry. 4th ed. Allured Publishing Corporation, Illinois, USA. 
Alvarenga, C. M. D. and Volpato, G. L. 1995. Agonistic profile and metabolism in alevins of the Nile tilapia. Physiology \& Behavior 57:75-80. https://doi.org/10.1016/0031-9384(94)00206-K

Barton, B. A. 2002. Stress in fishes: a diversity of responses with particular reference to changes in circulating corticosteroids. Integrative and Comparative Biology 42:517-525. https:// doi.org/10.1093/icb/42.3.517

Barton, B. A. and Iwama G. K. 1991. Physiological changes in fish from stress in aquaculture with emphasis on the response and effects of corticosteroids. Annual Review of Fish Diseases 1:3-26. https://doi.org/10.1016/0959-8030(91)90019-G

Becker, A. G.; Parodi, T. V.; Heldwein, C. G.; Zeppenfeld, C. C.; Heinzmann, B. M. and Baldisserotto, B. 2012. Transportation of silver catfish, Rhamdia quelen, in water with eugenol and the essential oil of Lippia alba. Fish Physiology and Biochemistry 38:789-796. https://doi.org/10.1007/s10695-011-9562-4

Becker, A. G.; Cunha, M. A.; Garcia L. O.; Zeppenfeld, C. C.; Parodi, T. V.; Maldaner, G.; Morel, A. F. and Baldisserotto, B. 2013. Efficacy of eugenol and the methanolic extract of Condalia buxifolia during the transport of the silver catfish Rhamdia quelen. Neotropical Ichthyology 11:675-681. https:// doi.org/10.1590/S1679-62252013000300021

Bezerra, P.; Fernandes, A. G.; Craveiro, A. A.; Andrade, C. H. S.; Matos, F. J. A.; Alencar, J. W.; Machado, M. I. L.; Viana, G. S. B.; Matos, F. F. and Rouquayrol, M. Z. 1981. Composição química e atividade biológica de óleos essenciais de plantas do Nordeste gênero Lippia. Ciência e Cultura 33:1-14.

Boyd, C. E. and Tucker, C. S. 1992. Water quality and pond soil analyses for aquaculture. Alabama Agricultural Experiment Station, Auburn University, Alabama.

Cho, J. S.; Kim, T. H.; Lim, J. M. and Song J. H. 2008. Effects of eugenol on $\mathrm{Na}^{+}$currents in rat dorsal root ganglion neurons. Brain Research 1243:53-62. https://doi.org/10.1016/j.brainres.2008.09.030

Cunha, M. A.; Barros, F. M. C.; Garcia, L. O.; Veeck, A. P. L.; Heinzmann, B. M.; Loro, V. L.; Emanuelli, T. and Baldisserotto, B. 2010a. Essential oil of Lippia alba: a new anesthetic for silver catfish, Rhamdia quelen. Aquaculture 306:403-406. https://doi.org/10.1016/j.aquaculture.2010.06.014

Cunha, M. A.; Zeppenfeld, C. C.; Garcia, L. O.; Loro, V. L.; Fonseca, M. B.; Emanuelli, T.; Veeck, A. P. D.; Copatti, C. E. and Baldisserotto, B. 2010b. Anesthesia of silver catfish with eugenol: time of induction, cortisol response and sensory analysis of fillet. Ciência Rural 40:2107-2114. https://doi.org/10.1590/S010384782010001000009

Cunha, M. A.; Silva, B. F.; Delunardo, F. A. C.; Benovit, S. C.; Gomes, L. C.; Heinzmann, B. M. and Baldisserotto, B. 2011. Anesthetic induction and recovery of Hippocampus reidi exposed to the essential oil of Lippia alba. Neotropical Ichthyology 9:683-688. https://doi.org/10.1590/S1679-62252011000300022

Day, M. D. and McAndrew, T. D. 2003. The biology and host range of Falconia intermedia (Hemiptera: Miridae), a potential biological control agent for Lantana camara (Verbenaceae) in Australia. Biocontrol Science and Technology 13:13-22. https://doi.org/10.1080/0958315021000054359

European Pharmacopoeia. 2007. 6th ed. European Directorate for the Quality of Medicines, Strassbourg.

Faturi, C. B.; Leite, J. R.; Alves, P. B.; Canton, A. C. and Teixeira-Silva, F. 2010. Anxiolytic-like effect of sweet orange aroma in Wistar rats. Progress in Neuro-Psychopharmacology \& Biological Psychiatry 34:605-609. https://doi.org/10.1016/j.pnpbp.2010.02.020

Gressler, L. T.; Riffel, A. P. K.; Parodi, T. V.; Saccol, E. M. H.; Koakoski, G.; Costa, S. T.; Pavanato, M. A.; Heinzmann, B. M.; Caron, B.; Schmidt, D.; Llesuy, S. F.; Barcellos, L. J. G. and Baldisserotto, B. 2014. Silver catfish Rhamdia quelen immersion anaesthesia with essential oil of Aloysia triphylla (L'Herit)
Britton or tricaine methanesulfonate: effect on stress response and antioxidant status. Aquaculture Research 45:1061-1072. https:// doi.org/10.1111/are.12043

Hennebelle, T.; Sahpaz, S.; Joseph, H. and Bailleul, F. 2008 Ethnopharmacology of Lippia alba. Journal of Ethnopharmacology 116:211-222. https://doi.org/10.1016/j.jep.2007.11.044

Hohlenwerger, J. C.; Copatti, C. E.; Sena, A. C.; Couto, R. D.; Baldisserotto, B.; Heinzmann, B. M.; Caron, B. O. and Schmidt, D. 2016. Could the essential oil of Lippia alba provide a readily available and cost-effective anaesthetic for Nile tilapia (Oreochromis niloticus)? Marine and Freshwater Behaviour and Physiology 49:119-126. https://doi.org/10.1080/10236244.2015.1123869

Joca, H. C.; Cruz-Mendes, Y.; Oliveira-Abreu, K.; Maia-Joca, R. P.; Barbosa, R.; Lemos, T. L.; Lacerda Beirao, P. S. and Leal-Cardoso, J. H. 2012. Carvacrol decreases neuronal excitability by inhibition of voltage-gated sodium channels. Journal of Natural Products 75:1511-1517. https://doi.org/10.1021/np300050g

Jukic, M.; Politeo, O.; Maksimovic, M.; Milos, M. and Milos, M. 2007. In vitro acetylcholinesterase inhibitory properties of thymol, carvacrol and their derivatives thymoquinone and thymohydroquinone. Phytotherapy Research 21:259-261. https://doi.org/10.1002/ptr.2063

Melo, F. H.; Venâncio, E. T.; de Sousa, D. P.; de França-Fonteles, M. M.; de Vasconcelos, S. M.; Viana, G. S. and Sousa, F. C. 2010. Anxiolytic-like effect of Carvacrol (5-isopropyl-2-methylphenol) in mice: involvement with GABAergic transmission. Fundamental \& Clinical Pharmacology 24:437-443. https://doi.org/10.1111/ j.1472-8206.2009.00788.x

Mommsen, T. P.; Vijayan, M. M. and Moon, T. W. 1999. Cortisol in teleosts: dynamics, mechanisms of action, and metabolic regulation. Reviews in Fish Biology and Fisheries 9:211-268. https://doi.org/10.1023/A:1008924418720

Mondello, L. 2011. FFNSC 2 Flavors and Fragrances of Natural and Synthetic Compounds - Mass Spectral Database. 2nd ed. Software, Wiley Online Library.

NIST/EPA/NIH. 2005. Mass spectral library and search/analysis programs. John Wiley and Sons, Hoboken, EUA.

O'Leary, N.; Denham, S. S.; Salimena, F. and Múlgura, M. E. 2012. Species delimitation in Lippia section Goniostachyum (Verbenaceae) using the phylogenetic species concept. Botanical Journal of the Linnean Society 170:197-219. https://doi. org/10.1111/j.1095-8339.2012.01291.x

Oliveira, D. R.; Leitão, G. G.; Santos, S. S.; Bizzo, H. R.; Lopes, D.; Alviano, C. S.; Alviano, D. S. and Leitão, S. G. 2006. Ethnopharmacological study of two Lippia species from Oriximiná, Brazil. Journal of Ethnopharmacology 108:103-108. https://doi.org/10.1016/j.jep.2006.04.018

Parodi, T. V.; Cunha, M. A.; Heldwein, C. G.; de Souza, D. M.; Martins, A. C.; Garcia, L. D.; Wasielesky, W.; Monserrat, J. M.; Schmidt, D.; Caron, B. O.; Heinzmann, B. and Baldisserotto, B. 2012. The anesthetic efficacy of eugenol and the essential oils of Lippia alba and Aloysia triphylla in post-larvae and sub-adults of Litopenaeus vannamei (Crustacea, Penaeidae). Comparative Biochemistry and Physiology Part C: Toxicology \& Pharmacology 155:462-468. https://doi.org/10.1016/j.cbpc.2011.12.003

Parodi, T. V.; Cunha, M. A.; Becker, A. G.; Zeppenfeld, C. C.; Martins, D. I.; Koakoski, G.; Barcellos, L. G.; Heinzmann, B. M. and Baldisserotto, B. 2014. Anesthetic activity of the essential oil of Aloysia triphylla and effectiveness in reducing stress during transport of albino and gray strains of silver catfish, Rhamdia quelen. Fish Physiology and Biochemistry 40:323-334. https://doi. org/10.1007/s10695-013-9845-z

Quintans-Júnior, L. J.; Guimarães, A. G.; Araújo, B. E. S.; Oliveira, G. F.; Santana, M. T.; Moreira, F. V.; Santos, M. R. V.; Cavalcanti, S. C. H.; De Lucca Júnior, W.; Botelho, M. A.; Ribeiro, L. A. A.; Nóbrega, F. F. F. and Almeida, R. N. 2010. Carvacrol, (-)-borneol 
and citral reduce convulsant activity in rodents. African Journal of Biotechnology 9:6566-6572.

Salbego, J.; Becker, A. G.; Gonçalves, J. F.; Menezes, C. C.; Heldwein, C. G.; Spanevello, R. M.; Loro, V. L.; Schetinger, M. R. C.; Morsch, V. M.; Heinzmann, B. M. and Baldisserotto, B. 2014. The essential oil from Lippia alba induces biochemical stress in the silver catfish (Rhamdia quelen) after transportation. Neotropical Ichthyology 12:811-818. https://doi.org/10.1590/ 1982-0224-20130178

Salbego, J.; Becker, A. G.; Parodi, T. V.; Zeppenfeld, C. C.; Gonçalves, J. F.; Loro, V. L.; Morsch, V. M. M.; Schetinger, M. R. C.; Maldaner, G.; Morel, A. F. and Baldisserotto, B. 2015. Methanolic extract of Condalia buxifolia added to transport water alters biochemical parameters of the silver catfish Rhamdia quelen. Aquaculture 437:46-50. https://doi.org/10.1016/ j.aquaculture.2014.11.022

Silva, L. L.; Parodi, T. V.; Reckziegel, P.; Garcia, V. O.; Bürger, M. E.; Baldisserotto, B.; Mallmann, C. A.; Pereira, A. M. S. and Heinzmann, B. M. 2012. Essential oil of Ocimum gratissimum L.: anesthetic effects, mechanism of action and tolerance in silver catfish, Rhamdia quelen. Aquaculture 350-353:91-97. https://doi. org/10.1016/j.aquaculture.2012.04.012.

Silva, L. L.; Silva, D. T.; Garlet, Q. I.; Cunha, M. A.; Mallmann, C. A.; Baldisserotto, B.; Longhi, S. J.; Pereira, A. M. S. and Heinzmann, B. M. 2013. Anesthetic activity of Brazilian native plants in silver catfish (Rhamdia quelen). Neotropical Ichthyology 11:443-451. https://doi.org/10.1590/S1679-62252013000200014

Singh, G.; Rao, G. P.; Kapoor, P. S. and Singh, O. P. 2000. Chemical constituents and antifungal activity of Lippia alba Mill. leaf essential oil. Journal of Applied Research on Medicinal and Aromatic Plants 22:701-703.

Small, B. C. 2003. Anesthetic efficacy of metomidate and comparison of plasma cortisol responses to tricaine methanesulfonate, quinaldine and clove oil anesthetized channel catfish Ictalurus punctatus. Aquaculture 218:177-185. https://doi.org/10.1016/ S0044-8486(02)00302-2

Souza, C. F.; Baldissera, M. D.; Salbego, J.; Lopes, J. M.; Vaucher, R. A.; Mourão, R. H. V.; Caron, B. O.; Heinzmann, B. M.; Silva, L. V. F. and Baldisserotto, B. 2017. Physiological responses of Rhamdia quelen (Siluriformes: Heptapteridae) to anesthesia with essential oils from two different chemotypes of Lippia alba. Neotropical Ichthyology 15:e160083. https://doi.org/10.1590/1982-0224-20160083

Souza, C. F.; Baldissera, M. D.; Bianchini, A. E.; Silva, E. G.; Mourão, R. H. V.; Silva, L. V. F.; Schmidt, D.; Heinzmann, B. M. and Baldisserotto, B. 2018. Citral and linalool chemotypes of Lippia alba essential oil as anesthetics for fish: a detailed physiological analysis of side effects during anesthetic recovery in silver catfish (Rhamdia quelen). Fish Physiology and Biochemistry 44:21-34. https://doi.org/10.1007/s10695-017-0410-z

Stashenko, E. E.; Martínez, J. R. and Ruíz, C. A. 2010. Lippia origanoides chemotype differentiation based on essential oil GC/MS and principal component analysis. Journal of Separation Science 33:93-103. https://doi.org/10.1002/jssc.200900452

Terblanché, F. C. and Kornelius, G. 1996. Essential oil constituents of the genus Lippia (Verbenaceae) - a literature review. Journal of Essential Oil Research 8:471-485. https://doi.org/10.1080/104129 05.1996.9700673

Toni, C.; Becker, A. G.; Simões, L. N.; Pinheiro, C. G.; Silva, L. L.; Heinzmann, B. M.; Caron, B. O. and Baldisserotto, B. 2014. Fish anesthesia: effects of the essential oils of Hesperozygis ringens and Lippia alba on the biochemistry and physiology of silver catfish (Rhamdia quelen). Fish Physiology and Biochemistry 40:701-714. https://doi.org/10.1007/s10695-013-9877-4

Toni, C.; Martos-Sitcha, J. A.; Baldisserotto, B.; Heinzmann, B. M.; Silva, L. L.; Martínez-Rodríguez, G. and Mancera, J. M. 2015. Sedative effect of 2-phenoxyethanol and essential oil of Lippia alba on stress response in gilthead sea bream (Sparus aurata). Research in Veterinary Science 103:20-27. https://doi.org/ 10.1016/j.rvsc.2015.09.006

Verdouw, H.; Echteld, C. J. A. and Dekkers, E. M. J. 1978. Ammonia determination based on indophenol formation with sodium salicylate. Water Research 12:399-402. https://doi.org/ 10.1016/0043-1354(78)90107-0

Zeppenfeld, C. C.; Toni, C.; Becker, A. G.; Miron, D. S.; Parodi, T. V.; Heinzmann, B. M.; Barcellos, L. J. G.; Koakoski, G.; da Rosa, J. G. S.; Loro, V. L.; Cunha, M. A. and Baldisserotto, B. 2014. Physiological and biochemical responses of silver catfish, Rhamdia quelen, after transport in water with essential oil of Aloysia triphylla (L'Herit) Britton. Aquaculture 418-419:101-107. https://doi.org/10.1016/j.aquaculture.2013.10.013 